ROCZNIKI TEOLOGICZNE

Tom LXVI, zeszyt 11 - 2019

DOI: http://dx.doi.org/10.18290/rt.2019.66.11-4

KS. STANISŁAW ŁABENDOWICZ

\title{
PRAWDA FUNDAMENTEM WYCHOWANIA
}

„Człowiek jest sobą poprzez prawdę i staje się bardziej sobą przez coraz pełniejsze poznanie prawdy"

św. Jan Paweł II

\section{TRUTH - THE FOUNDATION OF EDUCATION}

\begin{abstract}
A b s t r a c t. In each one of us there is an inborn need of the knowledge of everything that surrounds us and that in a true way. The love of truth reveals itself in the need to know it and to abide by it in our life. In coming to know the truth about the world which surrounds him, man gradually gains the aptitude of an independent distinguishing of truth from falseness. The securing of this capacity lets such a person be recognized as a mature human being. A most important element of education of the younger generation for truth is to show children and youth the person and life of Christ, who is not only the Truth, but also the Way, the Life and the Good (cf. J 14:6). For there is no education without a previous explaining of truth. Education in truth consists of seeking it, but also of giving testimony to it in the different circumstances of life. Education in truth is an education for a courageous life. For truth demands that we fearlessly stand by it and, should the need arise, defend it with courage, and even heroically sacrifice ourselves for it. The human being is called to a life in truth and love. This not only concerns those who educate, but also those who are educated.
\end{abstract}

Key words: truth; education; Christ - the Way, the Truth, the Life, the Good.

W każdym z nas istnieje wrodzona potrzeba poznawania wszystkiego, co nas otacza $\mathrm{i}$ to $\mathrm{w}$ sposób niezakłamany. Mamy nie tylko zdolność czynienia tego, ale jesteśmy także w stanie - po odpowiednim uformowaniu - poznać,

Ks. dr hab. STANISŁAW ŁABENDOWICZ, prof. KUL - adiunkt Katedry Katechetyki Integralnej na Wydziale Teologii Katolickiego Uniwersytetu Lubelskiego Jana Pawła II; adres do korespondencji - e-mail: slabendowicz@wp.pl 
czy coś jest prawdziwe, autentyczne. Można więc powiedzieć, że każdy człowiek nosi w sobie miłość do prawdy, która objawia się w potrzebie jej poznania i w dążeniu do zaspokojenia tej ciekawości ${ }^{1}$. Wychowanie jest „,celowym i świadomym działaniem pedagogicznym zmierzającym do osiąnięcia rozwoju fizycznego, umysłowego, społecznego i kulturowego jednostki ludzkiej”" . Z kolei celem wychowania w duchu chrześcijańskim, jako ,pomocy udzielanej człowiekowi w realizacji jego człowieczeństwa, w nadaniu życiu człowieka ostatecznego sensu rozumianego na ogół jako zjednoczenie człowieka z Bogiem poprzez praktykowanie miłości bliźniego" (Sobór Watykański II, Gravissimum educationis [dalej: GE], 2), jest dążenie do „kształtowania osoby ludzkiej w kierunku jej ostatecznego celu, a równocześnie do dobra społeczności, których człowiek jest członkiem i w których obowiązkach, gdy dorośnie, będzie brał udział" (GE 1). Ojciec Święty Jan Paweł II stwierdza, że okres młodości jest szczególnym momentem w życiu człowieka. Jest to „czas dany każdemu człowiekowi i równocześnie zadany przez Opatrzność. W tym czasie szuka on odpowiedzi na podstawowe pytania, jak młodzieniec z Ewangelii; szuka nie tylko sensu życia, ale szuka konkretnego projektu, wedle którego to swoje życie ma zacząć budować. I to właśnie jest najistotniejszy rys młodości”’3. Właśnie dlatego w okresie młodości człowiek najbardziej potrzebuje osób, które pokażą mu prawdę o świecie, o człowieku i o Bogu, a także pomoga mu rozeznać jego powołanie.

\section{PRAGNIENIE PRAWDY W ŻYCIU CZŁOWIEKA}

Prawda (z łac. veritas; z gr. $\grave{\lambda} \lambda \hat{\eta} \theta \varepsilon \imath \alpha$ [czyt. alètheia]), według definicji Stownika języka polskiego PWN jest to: „1. «zgodna z rzeczywistością treść słów, interpretacja faktów, przedstawienie czegoś zgodne z realiami»; 2. «to, co rzeczywiście jest, istnieje lub było»; 3. «zasada dowiedziona naukowo lub wynikająca $\mathrm{z}$ doświadczenia, uważana powszechnie za niepodważalną»"4. W człowieku, od początku jego istnienia, drzemie potrzeba odkrywania i po-

\footnotetext{
${ }^{1}$ Por. S. KLIMAS, Prawda jako droga do poznania siebie i poznania Boga, http://rmissio.pl/ pl/prawda-jako-droga-do-poznania-siebie-i-poznania-boga/ (dostęp: 27.09.2019); Prawda w nauczaniu Jana Pawła II, https://www.centrumjp2.pl/wikijp2/index.php?title=Prawda (dostęp: 27.09. 2019).

${ }^{2}$ S. ŁABENDOwICZ, Wychowanie do prawdy w katechezie, „Zeszyty Formacji Katechetów” 2015, nr 2(58), s. 56.

3 JAN PAWEe II, Przekroczyć próg nadziei, Lublin 1994, s. 101.

${ }^{4}$ Prawda, w: Stownik jezyka polskiego PWN, https://sjp.pwn.pl/sjp/prawda-I;2507920.html (dostęp: 21.10.2019).
} 
znawania tego, co go otacza. Potwierdza to Jan Paweł II w encyklice, mówiąc, iż „ «Wszyscy ludzie pragną wiedzieć», a właściwym przedmiotem tego pragnienia jest prawda. Nawet w życiu codziennym obserwujemy, jak bardzo każdy człowiek stara się poznać obiektywny stan rzeczy, nie zadowalając się informacjami z drugiej ręki. Człowiek to jedyna istota w całym widzialnym świecie stworzonym, która nie tylko zdolna jest wiedzieć, ale także zdaje sobie sprawę z tego, że wie, i dlatego pragnie poznać istotną prawdę tego, co postrzega. Nikomu nie może być naprawdę obojętne, czy jego wiedza jest prawdziwa. Jeśli człowiek odkryje, że jest fałszywa, odrzuca ją; jeśli natomiast może się upewnić o jej prawdziwości, doznaje satysfakcji” (Veritatis splendor [dalej: VS], 25). Dążenie do poznania prawdy jest więc wpisane w naturę człowieka, który ma nie tylko prawo do pozyskania prawdy, ale również moralny obowiązek do jej szukania, a w przypadku odnalezienia do wiernego trwania przy niej. Pragnienie prawdy - jak stwierdza Jan Paweł II - ,jest tak głęboko zakorzenione w sercu człowieka, że gdyby musiał się go wyrzec, prowadziłoby to do kryzysu egzystencjalnego" (Fides et ratio [dalej: FR], 28).

Poznając prawdę o otaczającym go świecie, człowiek stopniowo zyskuje zdolność samodzielnego odróżniania prawdy od fałszu. To właśnie nabycie tej umiejętności pozwala uznać go za człowieka dojrzałego. Jego dojrzałość objawia się tym, iż wybiera i dąży do tych wartości, które są prawdziwe i dzięki którym może stawać się coraz lepszy (por. VS 25). Dojrzały człowiek zdaje sobie sprawę, że nie jest „posiadaczem” prawdy ${ }^{5}$. Z tego względu musi otworzyć się na świat, a przede wszystkim na transcendentny wymiar otaczającej go rzeczywistości (por. VS 25). Jak zauważa Jan Paweł II, tu z pomoca przychodzi wiara chrześcijańska, która, wprowadzając w porządek łaski ${ }^{6}$, jednocześnie doprowadza go do całej prawdy, co dokonuje się ,w wierze i poprzez wiarę, co jest dziełem Ducha Prawdy i owocem Jego działania w człowieku. Duch Święty ma być tutaj najwyższym przewodnikiem człowieka; światłem ducha ludzkiego" (Dominum et Vivificantem [dalej: DV], 6). Wiara chrześcijańska ukazuje więc człowiekowi konkretną drogę do osiaggnięcia celu, jakim jest poznanie prawdy. Dzięki niej może „dostąpić udziału w tajemnicy Chrystusa, w Nim zaś zyskać prawdziwe i pełne poznanie Boga w Trójcy Jedynego. Tak więc w Jezusie Chrystusie, który jest Prawdą, wiara

\footnotetext{
${ }^{5}$ Por. Prawda w nauczaniu Jana Pawta II.

${ }^{6}$ Por. tamże.
} 
dostrzega najwyższe wezwanie, jakie zostaje skierowane do ludzkości, aby mogła spełnić to, czego pragnie i za czym tęskni” (FR 33).

Człowiek, jako istota wolna, może poznaną prawdę przyjąć i przy niej trwać lub też odrzucić ją i zwrócić się w stronę kłamstwa. Przyczyną porzucenia prawdy na rzecz fałszu jest następstwo popełnienia grzechu pierworodnego przez pierwszych rodziców pod wpływem kuszenia przez Szatana, który jest „kłamcą i ojcem kłamstwa” (J 8,44). Wydarzenie to spowodowało pokusę odwracania się człowieka od Boga, który jest Prawdą i kierowania się w stronę bożków, prowadzących go na manowce poprzez ukazywanie mu złudnego szczęścia ${ }^{7}$. Według Jana Pawła II od momentu grzechu pierworodnego u człowieka przytępiona została „zdolność poznawania prawdy i osłabiona wola poddania się jej. W konsekwencji człowiek, ulegając relatywizmowi i sceptycyzmowi (por. J 18,38), zaczyna szukać złudnej wolności poza samą prawdą. Ciemności błędu i grzechu nigdy jednak nie zdołają do końca zgasić w człowieku światła Boga Stwórcy. W głębi serca stale tęskni on za absolutną prawdą i pragnie w pełni ją poznać" (VS 1). Człowiek może wybrać fałsz zamiast prawdy, nie tylko $\mathrm{z}$ własnej niewiedzy, ale także może uczynić to w pełni świadomie, np. z obawy przed konsekwencjami wynikającymi z przyjętej prawdy. Jednak nawet wówczas prawda oddziałuje na jego życie ${ }^{8}$. Jak czytamy w Fides et ratio, „Człowiek nie może przecież oprzeć swego życia na czymś nieokreślonym, na niepewności albo na kłamstwie, gdyż takie życie byłoby nieustannie nękane przez lęk i niepokój. Można zatem określić człowieka jako tego, który szuka prawdy" (FR 28). Zaakceptowanie tej osądzającej prawdy wymaga od człowieka pokory. Potwierdza to R. Brague, stwierdzając, że ,jeśli światło prawdy byłoby jedynie osądem, byłoby nie do zniesienia, a pokora byłaby masochizmem. Jednak sąd utożsamia się z przebaczeniem. Jeśli historia zbawienia jako Boże przebaczenie udzielone ludziom, osiąga swój punkt kulminacyjny w wydarzeniu Chrystusa, to Chrystus jest prawdą, który przyszedł, nie żeby świat potępić, ale zbawić (por. J 3,16) i nie można ich rozdzielić, pretendując do wyboru pomiędzy prawdą i Bogiem, którego objawia Jezus Chrystus"9.

\footnotetext{
${ }^{7}$ S. KLIMAS, Prawda jako droga do poznania siebie i poznania Boga.

${ }^{8}$ Por. FR 28; Prawda w nauczaniu Jana Pawta II.

${ }^{9}$ S. KLIMAS, Prawda jako droga do poznania siebie i poznania Boga.
} 


\section{POZNANIE PRAWDY \\ WARUNKIEM ROZWOJU OSOBY LUDZKIEJ}

Człowiek pragnie poznania prawdy, a dążenie to wypływa z jego natury. Poznając prawdę, uzyskuje wiedzę na temat otaczającej go rzeczywistości widzialnej i niewidzialnej - i o nim samym. Informacje te są niezbędne do tego, aby mógł się prawidłowo i stale rozwijać oraz odkryć sens swojego istnienia. To właśnie światło obiektywnej prawdy winno prowadzić go do odkrywania wszelkich aspektów jego powołania zarówno w wymiarze doczesnym, jak i nadprzyrodzonym. Zdolność poznawania prawdy gwarantuje człowiekowi sam Bóg, który jest Prawdą (por. Jan Paweł II, Redemptor hominis [dalej: RH], 4) ${ }^{10}$. Poznawanie siebie, prowadzace do integracji osoby, nie jest czynnością dokonującą się w jednym momencie, lecz jest procesem przebiegającym w następujących po sobie etapach, na których człowiek coraz bardziej zagłębia się w siebie, ubogacając tym samym wiedzę o sobie samym $^{11}$. W życiu człowieka można wyróżnić cztery takie etapy: „Pierwszy etap jest niewyraźny, pierwotny, etap chaotyczny dziecka, które nie wie dokąd rozciąga się moje «ja». Następnie pojawia się świadomość postępująca mojego «ja»w opozycji do nie «ja». Kolejnym etapem jest świadomość własnego wnętrza w odniesieniu do ciała, które pozostaje na zewnątrz. Tej świadomości człowiek nabiera $\mathrm{z}$ czasem poprzez refleksję. W końcu następuje uduchowienie progresywne i wybór, który konstytuuje centrum osoby. Poprzez świadomy i wolny wybór realizuje się oryginalność osoby i jej niepowtarzalny charakter" ${ }^{\prime 2}$.

Poznanie samego siebie wymaga od człowieka spojrzenia w głąb siebie, do własnego wnętrza. Można powiedzieć, że poznawanie siebie jest pewnego rodzaju misterium - tajemnicą, którą stopniowo się odkrywa. Nieznajomość siebie, jak i fałszywe poznanie siebie mają to samo źródło - brak chęci poznania siebie samego, którego podstawą są egoizm, pycha, próżność oraz inne namiętności człowieka. To właśnie te skłonności są jakby „kotarami”, które zasłaniają człowiekowi blask prawdy, pozwalający mu dostrzec prawdziwy obraz samego siebie. Kolejnym czynnikiem, który to utrudnia, jest lęk przed podjęciem trudu pracy nad sobą, ciągłego doskonalenia się. Nie można także zapominać o podstępnym wpływie Szatana - „kłamcy i ojcu kłamstwa”, który

\footnotetext{
${ }^{10}$ Por. Prawda w nauczaniu Jana Pawta II.

${ }^{11}$ Por. S. Klimas, Prawda jako droga do poznania siebie i poznania Boga.

12 Por. tamże.
} 
ukazuje człowiekowi złudny obraz nie tylko jego samego, ale także fałszywe oblicze Boga, który jest Prawdą ${ }^{13}$. Człowiek pragnie wiedzieć, kim jest, dokąd zmierza, jaki jest sens jego życia. Dąży do coraz to głębszego odkrywania siebie. Poznanie to nie powinno być jedynie zaznajomieniem się z wymiarem cielesnym, ale winno również obejmować sferę psychologiczną, uczuciową, moralną i duchową. Takie poznanie wymaga od człowieka uznania własnej wielkości, wynikającej z godności dziecka Bożego, jak i swoich słabości, które są wynikiem oddalania się od Stwórcy poprzez popełniany grzech ${ }^{14}$. Tym, co pozwala człowiekowi powstrzymywać się przed popełnianiem zła, jest prawda, która jest prawdą sumienia ${ }^{15}$. To prawidłowo uformowane sumienie pozwala rozstrzygnąć, czy coś jest dobre czy złe, prawdziwe czy fałszywe, pożyteczne czy bezwartościowe, a nawet szkodliwe. Dzięki temu rozeznaniu może podążać za głosem swojego sumienia, czyli za prawdą lub też postępować przeciw niemu, wbrew prawdzie. Jak stwierdza Jan Paweł II: „W pierwszym wypadku - rośnie jako człowiek, staje się bardziej tym, kim ma być. W drugim wypadku

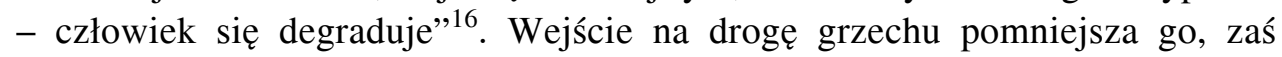
wkroczenie na ścieżkę cnoty czyni go większym ${ }^{17}$.

Wsłuchanie się w głos własnego sumienia jest jednym z elementów poznania siebie i życia w zgodzie z prawdą. Czynnikiem sprzyjającym temu celowi są również relacje interpersonalne. Człowiek potrzebuje bliskich, życzliwych mu osób, które chca jego dobra. Ludzie ci muszą być jednak wobec niego szczerzy, nawet wówczas, gdyby przekazywana mu prawda miała być dla niego bolesna. Jedynie poprzez kontakt $\mathrm{z}$ takimi osobami człowiek jest $\mathrm{w}$ stanie poznać własne, prawdziwe oblicze, ze wszystkimi swoimi zaletami, ale także ze wszystkimi wadami. Dzięki nim jest on także w stanie doskonalić się, stając się coraz lepszym człowiekiem. Poznanie siebie wymaga także samotności i wyciszenia ${ }^{18}$, ,aby przyjrzeć się sobie samemu twarzą w twarz, aby rozpoznać i zaakceptować jako osobiste zadanie, jako szukanie tego, by stać się sobą samym: to znaczy być człowiekiem pokornym, który uznaje w swojej niepowtarzalności zadanie, które dla niego jest możliwe i tylko przez niego jest realizowane, i kto nie sprzeniewierza się temu zadaniu, chro-

\footnotetext{
${ }^{13}$ Por. tamże, s. 1533.

14 Por. tamże.

15 Por. Jan PAWEe II, Homilia wygłoszona do młodzieży w czasie Mszy Świętej, Westerplatte, 12 czerwca $1987 \mathrm{r}$.

16 Tamże.

${ }^{17}$ Por. tamże.

18 Por. tamże; J.W. Gogola, Osoba i wspólnota, Kraków 2002, s. 87-89.
} 
niąc się w «stadzie», w anonimowości tłumu lub w zamknięciu się w sobie samym [...]. Chrześcijanin staje się człowiekiem żyjącym w prawdzie przed Bogiem, z samym sobą oraz z innymi. Jest zdolny do wypowiadania słowa odpowiadającego prawdzie o rzeczach i o osobach. Taka samotność jest wej-

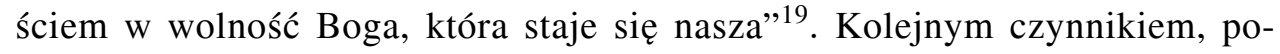
zwalającym człowiekowi poznać siebie samego, jest jego wolność osobista, której jednym z doświadczeń jest pokora, czyli sposób życia w prawdzie. Ten szczególny związek między wolnością a pokorą ukazał J. Tischner, stwierdzając, iż: „Pokora to szczególny «sposób bycia» człowieka, sposób przejawiania się jego dobrej woli. Człowiek, który «w niej jest», nie wynosi się «ponad siebie», ale również się «nie garbi», nie udaje nędzniejszego, niż jest. Człowiek jest taki, jaki jest. Pokora ma w sobie coś $\mathrm{z}$ wolności, którą rodzi w człowieku prawda"20.

Niezwykle ważny w poznawaniu siebie jest również osobisty kontakt człowieka z Bogiem, który jest Prawdą. Doświadczenie to następuje m.in. poprzez modlitwę oraz rozważanie słowa Bożego zawartego w Piśmie Świętym. To właśnie Boże słowo „obnaża sekretne myśli człowieka i odsłania jego serce, do którego grzech wprowadził niepokój i nieporządek, czyniąc je nieprzeźroczystym dla światła Bożego. Słowo przywraca wnętrzu człowieka Bożą jasność i daje klucz do odczytania prawdy o sobie. Tym kluczem jest oblicze Chrystusa, które odbija się na każdej stronie Biblii"21. Sam Jezus mówi o sobie, że jest «drogą i prawdą, i życiem» (J 14,6a), dlatego człowiek, chcąc poznać siebie, swoje zalety i wady, mocne i słabe strony, a także odkryć swoje powołanie i sens swojego życia, winien nieustannie weryfikować swoje życie z Jezusem Chrystusem - Synem Bożym, który stał się Człowiekiem i który w sposób prawdziwy i najpełniejszy objawia osobie ludzkiej jej człowieczeństwo. Potwierdza to Ojciec Święty Jan Paweł II, stwierdzając, iż: „Światłość Bożego oblicza jaśnieje pełnią swego piękna w obliczu Jezusa Chrystusa, w tym «obrazie Boga niewidzialnego» (por. Kol 1,15) i «odblasku Jego chwały» (por. Hbr 1,3), «pełnym łaski i prawdy» (por. J 1,14): On jest

${ }^{19}$ S. KLIMAS, Koinônia - wspólnota z Bogiem i braćmi. Realizacja nowotestamentalnej koinonii w monastycyzmie, Kielce 2017, s. 127-128; cyt. za: S. KLIMAS, Prawda jako droga do poznania siebie i poznania Boga; por. E. BIANCHI, Stowa dla życia, Kielce 2014, s. 166-167.

20 J. TISCHNER, Etyka wartości i nadziei, w: Wokót wartości, red. D. von Hildebrand, J.A. Kłoczowski, J. Paściak, J. Tischner, W drodze, Poznań 1984, s. 112, cyt. za: S. KLIMAS, Prawda jako droga do poznania siebie i poznania Boga.

${ }^{21}$ S. KLIMAS, Prawda jako droga do poznania siebie i poznania Boga; por. M. MAGRASSI, Biblia i modlitwa, Kraków 2002, s. 146. 
«drogą i prawdą i życiem» (J 14,6). Dlatego ostatecznej odpowiedzi na każde pytanie człowieka, zwłaszcza na jego pytania religijne i moralne, udziela jedynie Jezus Chrystus. Więcej: sam Jezus Chrystus jest odpowiedzią, jak przypomina Sobór Watykański II: «Tajemnica człowieka wyjaśnia się naprawdę dopiero w tajemnicy Słowa Wcielonego. Albowiem Adam, pierwszy człowiek, był figura przyszłego, mianowicie Chrystusa Pana. Chrystus, nowy Adam, już w samym objawieniu tajemnicy Ojca i Jego miłości objawia w pełni człowieka samemu człowiekowi i okazuje mu najwyższe jego powołanie» (Gaudium et spes, 22)" (VS 2).

\section{MOŻLIWOŚCI I SPOSOBY WYCHOWANIA DO PRAWDY}

Współczesne czasy charakteryzują się dążeniem do przekonania ludzkości, że nie istnieje żadna obiektywna prawda, a o tym, czy coś jest prawdziwe, czy fałszywe decyduje indywidualnie każdy człowiek, według własnego uznania. W takiej sytuacji wszelkie stałe wartości czy prawa przestają mieć rację bytu i są zastępowane przez prawa i wartości niestałe, zmienne. W ten sposób rodzi się relatywizm, w którym prawda zależy od „widzi mi się” człowieka, od jego wyborów. W takim przypadku można przyjąć z dużą dozą prawdopodobieństwa, że - w zdecydowanej większości - wybierze on to, co przyniesie mu korzyść, da radość i satysfakcję, nawet wówczas, gdy według obiektywnej prawdy jest to jawny fałsz, kłamstwo i zło. Rodzący się relatywizm przekłada się również na to, że każda osoba głosząca istnienie obiektywnej prawdy, pragnąca żyć według jej wskazań, odbierana jest jako osoba niepoważna, ograniczona, staroświecka, jako przedstawiciel „ciemnogrodu”. Niejednokrotnie spotyka się ona z lekceważeniem ze strony osób uważających siebie za „nowoczesnych” i „oświeconych”22. Przed rodzącym się relatywizmem ostrzegał Ojciec Święty Jan Paweł II, głosząc, iż: „W sytuacji, w której nie istnieje żadna ostateczna prawda będąca przewodnikiem dla działalności politycznej i nadająca jej kierunek, łatwo o instrumentalizację idei i przekonań dla celów, jakie stawia sobie władza. Historia uczy, że demokracja bez wartości łatwo przemienia się w jawny lub zakamuflowany totalitaryzm" (Centesimus annus [dalej: CA], 46). O lekceważeniu obiektywnej prawdy, jako źródle wszelkiego zła, wypowiadał się również papież Jan XXIII, stwierdza-

\footnotetext{
${ }^{22}$ Por. KomisJa EPISKOPATU POLSKI, „Wychowywać do prawdy”. List Pasterski z okazji IV Tygodnia Wychowania: (14-20 października 2014 r.), Warszawa, 10 czerwca 2014 r.
} 
jąc, że: „Wszelkie zło, które zatruwa jednostki i narody i które niepokoi umysły wielu ludzi, ma jedną przyczynę i jedno źródło: ignorowanie prawdy, a czasami nawet więcej niż ignorowanie [...] pogardę dla prawdy i lekkomyślne jej odrzucanie" ${ }^{23}$. W związku z tym jako paląca potrzeba jawi się ukazywanie ludziom obiektywnej prawdy, wychowywanie do niej oraz zachęcanie do trwania w niej i życia według jej wskazań.

Jan Paweł II, w liście skierowanym do rodzin, stwierdza, że wychowanie jest „wspólnym uczestnictwem w prawdzie i miłości, w tym ostatecznym celu, który stanowi powołanie człowieka ze strony Boga Ojca, Syna i Ducha Świętego" (Gratissimam sane [dalej: GS], 16). Głównym celem takiego wychowania jest doprowadzenie człowieka do tego, by stawał się bardziej człowiekiem. Osiągnąć to można jedynie przez wszechstronny i harmonijny rozwój: fizyczny, psychiczny, emocjonalny, intelektualny, społeczny, duchowy, religijny, moralny. Dzięki takiej formacji człowiek będzie w stanie urzeczywistniać w swoim życiu klasyczną triadę wartości Platona - przyjętą później również przez chrześcijaństwo - a mianowicie: prawdę (verum), dobro (bonum) i piękno (pulchrum). Tak ukształtowany człowiek nie tylko będzie w stanie żyć według tych wartości, a poznawszy je, będzie pragnął z radością wcielać je w swoje życie ${ }^{24}$. W chrześcijaństwie źródłem tych wartości jest Bóg Trójjedyny. Co więcej, jest On nie tylko źródłem tej triady, ale On sam jest Najwyższą Prawdą, Dobrem i Pięknem. W związku z tym chrześcijańscy wychowawcy powinni prowadzić swoich uczniów „nie tylko do spotkania z Jezusem Chrystusem [który jest Prawdą - S.Ł.], ale do zjednoczenia, a nawet głębokiej z Nim zażyłości" (Jan Paweł II, Catechesi tradendae [dalej: CT], 5). Dzięki temu wychowanek będzie w stanie poznać obiektywne: prawdę, dobro i piękno, które - wcielone w jego życie - umożliwią mu coraz pełniejsze urzeczywistnianie jego człowieczeństwa ${ }^{25}$. Ojciec Święty Jan Paweł II sugeruje, by podstawą takiego wychowania była pedagogika Chrystusa, który ,jest nauczycielem w pełnym tego słowa znaczeniu, nauczycielem cichym i pokornego serca. Jego pedagogia odznacza się mądrością, roztropnością i cierpliwością - jest to pedagogia wyczulona na innych, umiejąca dostrzegać ich potrzeby i oczekiwania, zawsze gotowa do reakcji na rozmaite ludzkie sytuacje" $"$.

\footnotetext{
${ }^{23}$ JAN XXIII, Myśli wyszukane. Wybór i wstęp A.E. Chiffolo, Kraków 2003, s. 91.

${ }^{24}$ JAN PAWE€ II, „Odnowa czlowieka i społeczeństwa dokonuje się za sprawa odnowy sumień”. Przemówienie Ojca Świętego do III grupy Biskupów, Watykan, 14 lutego 1998 r.

${ }^{25}$ Por. S. ŁABENDOWICZ, Wychowanie do prawdy $w$ katechezie, s. 57.

${ }^{26}$ Tamże, s. 65; zob. JAN PAWEŁ II, Jezus nauczyciel naszym wzorem. Przemówienie Ojca
} 
Rozszerzający się po całym współczesnym świecie relatywizm zmusza ludzi, odpowiedzialnych za wychowanie przyszłych pokoleń, do ukazywania swoim wychowankom obiektywnej prawdy, jej źródła, wartości i znaczenia w życiu człowieka. Wychowanie do prawdy polega na tym, aby na każdym etapie formowania ukazywać uczniom ostateczną prawdę o nich samych, o świecie, drugim człowieku i o Bogu. Jednak przekaz wiedzy to nie wszystko. Wychowanków należy również przekonywać do słuszności tych racji, dzięki czemu będą mogli je przyjąć i wcielić we własne życie. Ważne przy tym jest także to, by nie tylko przekazywać wychowankom tę prawdę, ale przede wszystkim nauczyć ich dążyć samodzielnie do odkrywania tych wartości i umiejętności rozróżniania dobra od zła, kłamstwa od fałszu, tego, co przynosi korzyść od tego, co szkodzi. Należy więc wskazywać im drogi do osiągnięcia takiego celu. Wówczas będzie można patrzeć $\mathrm{z}$ nadzieją na społeczeństwo złożone $\mathrm{z}$ dobrze uformowanych ludzi ${ }^{27}$. Obowiązek wychowywania przyszłego pokolenia spoczywa przede wszystkim na trzech środowiskach: rodzinie, szkole i parafii. We współczesnych czasach coraz częściej włączają się $\mathrm{w}$ to dzieło środki masowego przekazu, z Internetem na czele. Nie można tu także zapominać o wpływie grup rówieśniczych na młodego człowieka. Wszystkim tym instytucjom nie wolno nigdy zapominać, a tym bardziej negować tego, że każdy człowiek ma prawo do wychowania ku słusznym wartościom. Obowiązek wychowywania do tych wartości ,nigdy nie może być eliminowany czy osłabiany przez jakiekolwiek interesy polityki narodowej czy też ponadnarodowej. Dlatego konieczne jest wychowanie w prawdzie i do prawdy"28. Wychowanie młodego pokolenia wymaga obecności stałych i niepodważalnych praw i wartości. Jedną z takich wartości jest właśnie prawda ${ }^{29}$. W wychowaniu do niej niezbędna jest z kolei „stała obecność norm i obowiązków, które powinny być dopełnione określonym systemem wartości” ${ }^{30}$.

Źródłem pełnej i obiektywnej prawdy o świecie, człowieku i o Bogu jest Jezus Chrystus. Co więcej, jest nie tylko źródłem tej prawdy, ale On sam jest Prawdą (por. J 14,6a). Dlatego też jest On „Najwyższym Wychowawcą w szko-

Świętego wygłoszone do studentów, pracowników naukowych i administracyjnych Katolickiego Uniwersytetu „Sacro Cuore”, wygłoszone na Placu św. Piotra 13 kwietnia 2000 r., w: Wielki Jubileusz roku 2000, red. S. Dziwisz, H. Nowacki, S. Nasiorowski, P. Ptasznik, Librería Editrice Vaticana 2001, s. 220.

${ }^{27}$ Por. KOMISJA EPISKOPATU POLSKI, „Wychowywać do prawdy”.

${ }^{28}$ BENEDYKT XVI, Przemówienie do ambasadorów sześciu krajów przy Stolicy Apostolskiej, Watykan 2013, za: Papież o wychowaniu młodzieży w prawdzie, https://www.deon.pl/ ko sciol/papiez-o-wychowaniu-mlodziezy-w-prawdzie,125145 (dostęp: 27.09.2019).

${ }^{29}$ Por. S. Łabendowicz, Wychowanie do prawdy w katechezie, s. 65-67.

30 Tamże, s. 65. 
le Prawdy”31 i to On dysponuje „wyraźnie określonym planem wychowawczym, wyrażającym się w słowach: «Nikt nie przychodzi do Ojca inaczej jak tylko przeze Mnie» (J 14,6b). Tym samym wskazuje na cel, do którego pragnie zaprowadzić wszystkich wierzacych w Niego. Jest nim dom Ojca. Nie ma bowiem dla człowieka nic ważniejszego niż jego własne zbawienie. Ono jest najwyższą wartością" 32 . Dlatego też Osoba Jezusa Chrystusa oraz Jego pedagogika winny być wzorem dla ludzi, którym bliska jest troska o wychowanie i rozwój przyszłego pokolenia. Osoby takie muszą pamiętać, iż dzieci i młodzież potrzebują nie tylko przekazu wiedzy, ale przede wszystkim przykładu życia, co potwierdził Ojciec Święty Paweł VI, stwierdzając, że: „Człowiek naszych czasów chętniej słucha świadków aniżeli nauczycieli; a jeśli słucha nauczycieli, to dlatego, że są świadkami" (Paweł VI, Evangelii nuntiandi, [dalej: EN], 41). Doprecyzował to w swojej homilii Jan Paweł II, który, zwracając się do dorosłych, powiedział: „Młodzi [...] was potrzebują. Oni poszukują wzorców, które byłyby dla nich punktem odniesienia. Oczekują odpowiedzi na wiele zasadniczych pytań, jakie nurtują ich umysły i serca, a nade wszystko domagają się od was przykładu życia" ${ }^{33}$. Osoby odpowiedzialne za kształtowanie młodzieży muszą być świadome, że głoszenie obiektywnej prawdy często łączy się z cierpieniem. Nie zawsze jest to cierpienie fizyczne, częściej jest to cierpienie psychiczne - wyśmiewanie, szykany, lekceważenie, poniżanie. W takich przypadkach winni oni mieć zawsze przed oczami obraz Chrystusa, który nie tylko „na to się narodził i na to przyszedł na świat, aby dać świadectwo prawdzie" (J 18,37), ale dla tej prawdy cierpiał i dla niej poniósł ofiarę swojego życia. Wcześniej podobną drogą kroczyli prorocy Starego Testamentu, a po śmierci Zbawiciela jego wyznawcy. Również dzisiaj nie brakuje osób poświęcających się dla prawdy. Także współcześnie zdarzają się osoby, które głoszenie poznanej prawdy przypłacają męczeńską śmiercią. Takiego zaangażowania w obronę prawdy Jezus wymaga od każdego swojego ucznia, dlatego każdy wierny powinien wejść na drogę prawdy i nią kroczyć, nawet kosztem doznawanego cierpienia ${ }^{34}$. Mając na uwadze ten trud, jaki muszą podjąć osoby formujące młode pokolenie, biskupi polscy zwrócili się do nich z apelem: „Nie bójcie się prawdy! Dążcie do niej z odwagą i zapałem! Uczcie jej innych! Wychowujcie do niej wszystkich, których Wam Pan Bóg powierzył! Nie dajcie

\footnotetext{
31 KomisJa EPISKOPATU POLSKI, „Wychowywać do prawdy”.

32 Tamże.

33 JAN PAWEŁ II, Homilia wygłoszona w czasie Mszy Świętej, Łowicz, 14 czerwca 1999 r.

${ }^{34}$ Por. KomisJa EPISKOPATU POLSKI, „Wychowywać do prawdy”.
} 
się zwieść namiastkami prawdy czy półprawdami! Brońcie się przed manipulacją ze strony tych, którzy są niechętni Chrystusowi i Jego Kościołowi. Nie oni maja być dla Was wzorami i autorytetami, ale Jezus Chrystus - nasz Pan i Zbawiciel, który oddał swoje życie za prawdę i sam o sobie mówi, że jest «drogą i prawdą, i życiem». Zdobywajcie umiejętność stawania w prawdzie o sobie poprzez częsty i rzetelny rachunek sumienia oraz przez regularne przystępowanie do sakramentu pokuty i pojednania! Tylko wtedy poznacie autentyczną radość, wynikającą z doświadczania słów Pana Jezusa: «Poznacie prawdę, a prawda was wyzwoli» (J 8,32)"35.

Na ważkość wychowywania do prawdy młodego pokolenia wskazywał Jan XXIII, głosząc, iż: „Matki uczą dzieci niechęci do kłamstwa; kiedy mijają lata, dorosły człowiek jasno uświadamia sobie, że prawda zawsze nas ocala, że zawsze należy odrzucać wszelki kompromis w kwestii prawdy i że w stosunkach społecznych honor człowieka ocenia się na podstawie jego wierności prawdzie w każdym czasie" ${ }^{36}$. I tu, wobec szerzących się we współczesnym świecie: relatywizmu, zakłamania i fałszu, rodzi się pytanie: Jak wychowywać młode pokolenie do prawdy? Po pierwsze osoby odpowiedzialne za formowanie dzieci i młodzieży, m.in. rodzice, nauczyciele, wychowawcy, pedagodzy, księża, powinni zacząć od siebie. Winni wyciągać wnioski płynące z przypowieści o drzazdze i belce w oku, o zbożu i chwastach, czy o budowaniu domu na piasku i skale. Nie można formować innych, przekazywać innym prawdziwych wartości, nie będąc samemu ukształtowanym i nie żyjąc według przekazywanych prawd. Dlatego też winni oni stale rozwijać się, podnosić swoje kwalifikacje pedagogiczno-psychologiczne, zacząć wymagać od siebie, by sprostać stawianym im wysokim wymaganiom etycznym. Osoby te winny wychowywać młode pokolenie nie tylko słownym przekazem wiedzy, ale przede wszystkim przykładem własnego życia ${ }^{37}$. W tym miejscu należy jeszcze raz podkreślić słowa Ojca Świętego Pawła VI, który twierdził, że: „Człowiek naszych czasów chętniej słucha świadków aniżeli nauczycieli; a jeśli słucha nauczycieli, to dlatego, że są świadkami” (EN 41).

Niezwykle ważnym elementem wychowywania do prawdy młodego pokolenia jest przedstawienie dzieciom i młodzieży Osoby i życia Chrystusa, który jest nie tylko Prawdą, ale także Drogą, Życiem i Dobrem (por. J 14,6). Nie

\footnotetext{
35 Tamże.

36 JAN XXIII, Myśli wyszukane, s. 92.

${ }^{37}$ Por. Wychowanie do prawdy, https://parafiajugow.pl/parafianie,napisali,forum,parafii,ju gow,27.html (dostęp: 27.09.2019); S. ŁABENDOWICZ, Wychowanie do prawdy w katechezie, s. 61-62.
} 
ma bowiem wychowania bez uprzedniego ukazania Prawdy ${ }^{38}$. To właśnie Syn Boży pokazuje nam, jak winno wyglądać życie w prawdzie. Wyjaśnia On, jak należy do prawdy dążyć, jak i gdzie jej poszukiwać. On także jest przykładem trwania przy znalezionej prawdzie, nawet za cenę własnego życia. Sam o sobie mówił, że: „na to się narodziłem i na to przyszedłem na świat, aby dać świadectwo prawdzie" (J 18,37). Ukazywanie Osoby Chrystusa Prawdy „budzi oddźwięk, angażuje osobiście, prowadzi do działania. Jest to trudne, ale konieczne, bo jest drogą do świadomego i wolnego zaangażowania"39. Właściwe kształtowanie sumienia dzieci i młodzieży jest kolejnym czynnikiem wychowywania do prawdy. Jak stwierdza Ojciec Święty Benedykt XVI, człowiek ,jest sobą poprzez wewnętrzną prawdę. Jest to prawda sumienia, odbita $\mathrm{w}$ czynach. $\mathrm{W}$ tej prawdzie każdy człowiek jest zadany samemu sobie" 40 . Podstawą każdego prawego sumienia jest prawo naturalne, Dekalog, przykazanie miłości oraz osiem błogosławieństw. W nich zawarta jest wola Boga, której rozeznawanie jest niczym innym, jak poszukiwaniem prawdy ${ }^{41}$. Tak więc życie według wskazań Bożych to życie w prawdzie, które „pozwala właściwie osądzić stan swojego ducha, a zarazem zdobyć się na wysiłek wewnętrznej przemiany. Będzie ona możliwa, jeśli w szkole Chrystusa-Prawdy będziemy Go uważnie słuchać, głębiej poznawać i pozwalać, aby nas prowadził ku pełnej prawdzie o Bogu i o nas samych"42. Przy kształtowaniu prawego sumienia dużą rolę odgrywa braterskie upomnienie w przypadku grzechu popełnianego przez bliźniego. W takim przypadku należy jednak pamiętać, by piętnować popełniane zło, a nie osobę dokonującą ten $\operatorname{czyn}^{43}$. W wychowywaniu dzieci i młodzieży do prawdy szczególnie istotne jest również kształtowanie przekonań. Papież Jan Paweł II wskazywał, że konieczne jest, żeby „wartości, które człowiek wybiera i do których dąży swoim życiem, były prawdziwe, ponieważ tylko dzięki prawdziwym wartościom może stawać się lepszy, rozwijając w pełni swoją naturę. Człowiek nie znajduje prawdziwych wartości zamykając się w sobie, ale otwierając się i poszukując ich także w wymiarach transcendentnych wobec niego samego. Jest to konieczny warunek, który każdy musi spełnić, aby stać się sobą

\footnotetext{
${ }^{38}$ Por. S. ŁABENDOwiCZ, Wychowanie do prawdy w katechezie, s. 61-62.

39 Tamże, s. 62.

40 J. RAtZinger, Drogi wiary w dobie wspótczesnych przemian, „Communio” 1992, nr 2(12), s. 125-128.

${ }^{41}$ Komisja EPISKOPATU POLSKI, „Wychowywać do prawdy”.

42 Tamże.

${ }^{43}$ Por. tamże.
} 
i wzrastać jako osoba dorosła i dojrzała" (FR 25). Przekazanie wychowankom prawdziwych wartości oraz ukształtowanie w nich postawy życia według przyjętych norm i obrony własnych przekonań doprowadzi wychowanków do dojrzałości nie tylko w wierze, ale również w ich codziennym życiu. Pozwoli im to także na dokonywanie słusznych wyborów życiowych ${ }^{44}$.

W chrześcijańskim wychowaniu do prawdy należy korzystać z religijnych środków nadprzyrodzonych, którymi są m.in. modlitwa, sakramenty czy Biblia. Bliskość i łaska Boga potrzebna jest nie tylko wychowankom, ale również tym, którzy ich formują. Zarówno jedni, jak i drudzy muszą pamiętać, że to właśnie Bóg jest najlepszym wychowawcą i to On ukazuje obiektywną prawdę, gdyż to On sam jest Prawdą. W wychowaniu do prawdy ważną rolę odgrywa kultura. To właśnie ona stanowiła dla Ojca Świętego Jana Pawła II propedeutykę życia moralnego. „Człowiek jest jedynym podmiotem kultury - w niej się wyraża i w niej potwierdza. Kultura jest zatem dynamicznym aspektem wychowania, a najważniejszymi jej wymiarami są kultura miłości i kultura pracy. Wychowanie w kulturze i poprzez kulturę stawia sobie za cel dostarczenie człowiekowi symboli, norm, wzorów i wartości" ${ }^{45}$. Ważna jest tu umiejętność odróżnienia prawdziwej sztuki od kiczu, pseudokultury czy wręcz antykultury. Jedynie prawdziwa sztuka dostarcza człowiekowi autentycznych wartości i wzorów postępowania. Wychowanie do życia w prawdzie to wychowanie do życia odważnego. Prawda bowiem wymaga od człowieka nieustraszonego trwania przy niej, a w razie potrzeby - mężnej jej obrony, a nawet heroicznego poświęcania się dla niej ${ }^{46}$. Poznana prawda wymaga od człowieka także podporządkowywania jej swojego życia ${ }^{47}$. Wychowywanie młodego pokolenia do prawdy wymaga poznania jej, wcielenia jej w swoje życie i postępowanie według jej wartości oraz umiejętności obrony własnych przekonań. To wszystko możliwe jest jedynie wówczas, gdy człowiek rozwinie u siebie umiejętność rozróżniania dobra od zła, prawdy od fałszu. We współczesnych czasach jest to coraz trudniejsze. Rozprzestrzeniający się po świecie relatywizm sprawia, że obiektywna prawda zaciemnia się, a w jej miejsce wchodzą subiektywne wybory ludzkie. Prawdą staje się to, co jest dla człowieka wygodne, korzystne, co sprawia mu radość. Co więcej, w takim

\footnotetext{
${ }^{44}$ Por. S. Łabendowicz, Wychowanie do prawdy w katechezie, s. 61-62.

45 Tamże, s. 66; por. Jan PAWEŁ II, W imię przyszłości kultury. Przemówienie Ojca Świętego w siedzibie UNESCO (2 czerwca 1980 r.), w: Jan Pawet II, Nauczanie papieskie, t. 3, cz. I, Poznań-Warszawa 1985, s. 731.

${ }^{46}$ Por. Wychowanie do prawdy.

${ }^{47}$ KomisJa EPISKOPATU POLSKI, „Wychowywać do prawdy”.
} 
przypadku to, co dzisiaj jawi się jako prawda, jutro może już nią nie być, gdyż może człowieka znudzić, czy przestać mu odpowiadać. Brak obiektywnej prawdy sprawia, że człowiek nie ma się na czym „oprzeć”, wszystko, co teraz jest dla niego prawdą, w każdej chwili może okazać się fałszem. Żyjąc w takim świecie, czuje się zagubiony, niepewny. Dlatego tak ważne jest wychowanie człowieka do prawdy już od najmłodszych lat życia. Odniesienie do stałych wartości pozwala mu uzyskać spokój, pewność siebie, umożliwia podejmowanie trafnych decyzji życiowych.

Wychowanie w prawdzie polega na poszukiwaniu, ale i świadczeniu o niej w różnych sytuacjach życiowych. Zadaniem rodziców i wychowawców jest wytworzenie między nim a dzieckiem relacji opartej na szczerości i prawdzie. Potrzebne jest zaufanie, aby wychowanek czuł, że w każdej chwili może zwierzyć się rodzicom i wychowawcom ze swoich problemów i trudności. Człowiek jest powołany do życia w prawdzie i miłości. Odnosi się to zarówno do tych, którzy wychowują, jak i do tych, którzy są wychowywani. W Liście Pasterskim Episkopatu Polski biskupi przestrzegają przed tzw. dyktaturą relatywizmu. Chodzi w niej o podważanie i odrzucanie niezmiennych wartości, co doprowadza na przykład do aborcji czy eutanazji. Należy zatem podkreślić ogromną wartość wychowania w prawdzie i do życia prawdą. Brak takiego podejścia może doprowadzić do ,sytuacji, w której nie istnieje żadna ostateczna prawda będąca przewodnikiem [...], łatwo o instrumentalizację idei i przekonań" (CA 46). Wychowanie do prawdy w katechezie polega „na tym, aby na wszystkich etapach procesu wychowawczego - dokonującego się w domach, w przedszkolach i szkołach - rodzice oraz katecheci, nauczyciele i wychowawcy ukazywali wartość odkrywania ostatecznej prawdy o świecie, o człowieku i o Bogu. Ważne jest przy tym, aby pokazywali oni, jak do tej prawdy dążyć i w jaki sposób kierować się nią w codziennym życiu. W ten sposób dzieci i młodzież znajdą się w szkole prawdy i będą wychowywani przez prawdę. Tylko wtedy będziemy mogli z ufnością patrzeć w przyszłość, mając pewność, że dzięki temu ukształtuje się społeczeństwo, w którym ludzie będą kierowali się wewnętrzną uczciwością, prawością i rzetelnością"48.

Zadanie wychowania do prawdy i w prawdzie jest bardzo ważne, gdyż, jak to wskazał Pan Jezus: „Poznacie prawdę, a prawda was wyzwoli” (J 8,32). Droga ku poznaniu prawdy wymaga wielu wyrzeczeń i stawiania wymagań zarówno przed dziećmi, jak i wychowawcami. Do podążania taką właśnie drogą zachęcają biskupi, zwracając się z apelem do wszystkich tych, którzy

\footnotetext{
48 Tamże.
} 
wychowują dzieci i młodzież: „Nie bójcie się prawdy! Dążcie do niej z odwagą i zapałem! Uczcie jej innych! Wychowujcie do niej wszystkich, których Wam Pan Bóg powierzył! Nie dajcie się zwieść namiastkami prawdy czy półprawdami! Brońcie się przed manipulacją ze strony tych, którzy są niechętni Chrystusowi i Jego Kościołowi. [...] Zdobywajcie umiejętność stawania w prawdzie o sobie poprzez częsty i rzetelny rachunek sumienia oraz przez regularne przystępowanie do sakramentu pokuty i pojednania!"49. Również papież Benedykt XVI podkreśla, że „w obliczu mroków, które dziś zaciemniają horyzont świata, wzięcie odpowiedzialności za wychowanie [...] do poznania prawdy, podstawowych wartości życia, cnót intelektualnych, teologalnych i moralnych oznacza patrzenie w przyszłość z nadzieją. A do tego zadania integralnego wychowania należy także wychowanie do sprawiedliwości i pokoju"

\section{Wskazania do podmiotowego wychowania:}

- atmosfera prawdy i szczęścia w rodzinie chrześcijańskiej jest najlepszym podłożem wychowania;

- szczególnie w pierwszych sześciu latach życia wszystko, co rodzice dziecka czynią, jak się z nim obchodzą, co i jak do niego mówią, ma wpływ na nabywanie przez niego doświadczeń religijnych;

- życie religijne dziecka umożliwia jego głęboka więź z dojrzałymi religijnie rodzicami, konkretnymi osobami w obrębie tej wspólnoty, w której dziecko przeżywa liturgię;

- wychowanie do prawdy oparte jest głównie na świadectwie rodziców, wychowawców, ale również rówieśników i współczesnych mediów;

- rodzice powinni odkrywać przed dzieckiem oczekiwania, jakie Bóg ma w stosunku do każdego człowieka;

- wychowanie religijne może być w pełni skuteczne, jeśli jest jednolite i w pełni przemyślane ${ }^{51}$.

\footnotetext{
49 Tamże.

${ }^{50}$ BENEDYKT XVI, „Wychowanie jest integralna częścia ewangelizacji”. Homilia w czasie Mszy Świętej w uroczystość Świętej Bożej Rodzicielki Maryi, Watykan, 1 stycznia 2012 r.

${ }^{51}$ Por. S. ŁABENDOwICZ, Wychowanie do prawdy w katechezie, s. 67-68.
} 


\section{BIBLIOGRAFIA}

BENEDYKT XVI, „Wychowanie jest integralną częścią ewangelizacji”. Homilia w czasie Mszy Świętej w uroczystość Świętej Bożej Rodzicielki Maryi, Watykan, 1 stycznia 2012 r.

BENEDYKT XVI, Przemówienie do ambasadorów sześciu krajów przy Stolicy Apostolskiej, Watykan 2013, za: Papież o wychowaniu młodzieży w prawdzie, https://www.deon.pl/kos ciol/papiez-o-wychowaniu-mlodziezy-w-prawdzie,125145 (dostęp: 27.09.2019).

BiAnCHI E., Słowa dla życia, Kielce 2014.

Gogola J.W., Osoba i wspólnota, Kraków 2002.

JAN PAWEŁ II, „Odnowa człowieka i społeczeństwa dokonuje się za sprawą odnowy sumień”. Przemówienie Ojca Świętego do III grupy Biskupów, Watykan, 14 lutego 1998 r.

JAN PAWEŁ II, Homilia wygłoszona do młodzieży w czasie Mszy Świętej, Westerplatte, 12 czerwca $1987 \mathrm{r}$.

JAN PAWE€ II, Homilia wygłoszona w czasie Mszy Świętej, Łowicz, 14 czerwca 1999 r.

JAN PAWEŁ II, Jezus nauczyciel naszym wzorem. Przemówienie Ojca Świętego wygłoszone do studentów, pracowników naukowych i administracyjnych Katolickiego Uniwersytetu „Sacro Cuore”, wygłoszone na Placu św. Piotra 13 kwietnia 2000 r., w: Wielki jubileusz roku 2000, red. S. Dziwisz, H. Nowacki, S. Nasiorowski, P. Ptasznik, Librería Editrice Vaticana 2001.

JAN PAWEE II, Przekroczyć próg nadziei, Lublin 1994.

JAN PAWEe II, W imię przyszłości kultury. Przemówienie Ojca Świętego w siedzibie UNESCO (2 czerwca 1980 r.), w: JAN PAWE€ II, Nauczanie papieskie, t. 3, cz. I, Poznań-Warszawa 1985.

JAN XXIII, Myśli wyszukane. Wybór i wstęp A.E. Chiffolo, Kraków 2003.

KLIMAS S., Koinônia - wspólnota z Bogiem i braćmi. Realizacja nowotestamentalnej koinonii w monastycyzmie, Kielce 2017.

KLIMAS S., Prawda jako droga do poznania siebie i poznania Boga, http://rmissio.pl/pl/prawda jako-droga-do-poznania-siebie-i-poznania-boga/ (dostęp: 27.09.2019).

KoMISJA EPISKOPATU POLSKI, „Wychowywać do prawdy”. List Pasterski z okazji IV Tygodnia Wychowania (14-20 października 2014 r.), Warszawa, 10 czerwca 2014 r.

ŁaBENDOwICZ S., Wychowanie do prawdy w katechezie, „Zeszyty Formacji Katechetów” 2015, 2(58).

MAgRASSI M., Biblia i modlitwa, Kraków 2002.

Prawda w nauczaniu Jana Pawła II, https://www.centrumjp2.pl/wikijp2/index.php?title=Prawda (dostęp: 27.09.2019).

Prawda, w: Słownik języka polskiego PWN, https://sjp.pwn.pl/sjp/prawda-I;2507920.html (dostęp: 21.10.2019).

RATZINGER J., Drogi wiary w dobie współczesnych przemian, „Communio” 1992, nr 2(12).

TISCHNER J., Etyka wartości i nadziei, w: Wokół wartości, red. D. von Hildebrand, J.A. Kłoczowski, J. Paściak, J. Tischner, W drodze, Poznań 1984.

Wychowanie do prawdy, https://parafiajugow.pl/parafianie,napisali,forum,parafii,jugow,27.html, (dostęp: 27.09.2019). 


\section{PRAWDA FUNDAMENTEM WYCHOWANIA}

S t r e s z c z e n i e

W każdym z nas istnieje wrodzona potrzeba poznawania wszystkiego, co nas otacza i to w sposób niezakłamany. Miłość do prawdy objawia się w potrzebie jej poznania i w dążeniu do niej w życiu. Poznając prawdę o otaczającym go świecie, człowiek stopniowo zyskuje zdolność samodzielnego odróżniania prawdy od fałszu. Nabycie tej umiejętności pozwala uznać go za człowieka dojrzałego. Niezwykle ważnym elementem wychowywania do prawdy młodego pokolenia jest ukazanie dzieciom i młodzieży Osoby i życia Chrystusa, który jest nie tylko Prawdą, ale także Drogą, Życiem i Dobrem (por. J 14,6). Nie ma bowiem wychowania bez uprzedniego ukazania Prawdy. Wychowanie w prawdzie polega na poszukiwaniu, ale i na świadczeniu o niej w różnych sytuacjach życiowych. Wychowanie w prawdzie to wychowanie do życia odważnego. Prawda bowiem wymaga od człowieka nieustraszonego trwania przy niej, a w razie potrzeby - mężnej jej obrony, a nawet heroicznego poświęcania się dla niej. Człowiek jest powołany do życia w prawdzie i miłości. Odnosi się to zarówno do tych, którzy wychowują, jak i do tych, którzy są wychowywani.

Słowa kluczowe: prawda; wychowanie; Chrystus - Droga, Prawda, Życie, Dobro. 